\title{
Feeding behavior of goats, castrated and uncastrated, supplemented with Vitamin E
}

\author{
Igor Cassiano Saraiva Silva'*, José Antônio Alves Cutrim Junior², Edneide Marques da Silva², \\ Anderson Lopes Pereira ${ }^{3}$, Saulo Antônio Araújo Mesquita ${ }^{2}$, Ravana Sousa Gomes ${ }^{3}$ \\ 'State University Vale do Acaraú, Sobral, Brazil \\ ${ }^{2}$ Federal Institute of Education, Science and Technology of Maranhão, São Luís, Brazil \\ 3State University of Maranhão, Chapadinha, Brazil \\ *Corresponding author, email: cassianoigor1@hotmail.com
}

\begin{abstract}
The objective of this study was to evaluate the ethological and feeding behavior of male goats under the influence of climatic conditions, castration and supplementation with Vitamin E. The responses were analyzed by a behavior test factorial design with $2 \times 2$ (not spayed or neutered animal, the presence or absence of supplementation with Vitamin E), with 6 replicates. The time of feed intake, rumination, other activities, entertainment, salt intake frequency, water, urination and defecation were evaluated. The factors did not have any effect on the animal's condition, or the vitamin supplementation ( $P>0.05$ ) on rumination, other activities, defecation frequency and water consumption. Vitamin $E$ intake had no effect on food and entertainment ( $P>0.05)$. There was a significant condition of the animal $(\mathrm{P}<0.05)$ on the salt intake and urination, for uncastrated animals without Vitamin $E$. Periods of the day $(P<0.05)$ affected feed intake in all treatments. There was a significant difference $(P<0.05)$ for rumination time. Vitamin $E$ had little influence on ethological behavior, and castration is directly linked to the behavioral parameters of goats.
\end{abstract}

Keywords: castration, etiology, vitamin supplementation

\section{Introduction}

In order to achieve higher productive performance in goat breeding, it is necessary to make use of an adequate nutritional plan, so that the productive potential and nutrition are well correlated. With regard to the diet of these animals, the supply of nutrients in optimum proportions and which meet the requirements are fundamental elements for the success of the production system.

To evaluate the effect of diets offered to goats and their relationship with productive performance, it is important to evaluate their ingestive behavior in order to adjust the nutritional management to achieve better food efficiency.
The sex, weight, composition, and acceptability of foods are some of the factors to be considered in formulating rations for small ruminants. In addition to these, the environment should be taken into account, because when under stress conditions, animals decrease their consumption as a function of maintaining the internal body temperature, which demonstrates the importance of maintaining facilities with environmental indexes close to the comfort conditions.

One of the management strategies for constant improvement of the goat breeding production chain is castration, a practice widely used to prevent animals of low genetic 
potential from reproducing. Parallel to this, it facilitates management due to inhibition of the production of testosterone, consequently decreasing the expression of the most aggressive behavior of males, besides improving the carcass characteristics of slaughtered animals later.

Vitamin E (alpha-tocopherol) has been gaining grounds in production, as it is an essential nutrient that protects tissues from oxidative damage, besides assisting in the growth and maintenance of animal health. This protective effect can be carried to the meat and improved through dietary supplementation, with amounts greater than those required for normal growth (Kasapidou et al., 2012). However, little is known about its effects on the behaviour of these animals.

Thus, the objective of this study was to evaluate the ingestive behavior of goats under the influence of the environmental conditions of confinement, castration and supplementation with vitamin $\mathrm{E}$.

\section{Materials and Methods}

The research was conducted in the Sector of Ovinocaprinoculture of the Federal Institute of Education, Science and Technology of Maranhão, São Luis Campus - Maracanã. It is located at $35 \mathrm{~m}$ of altitude, south latitude

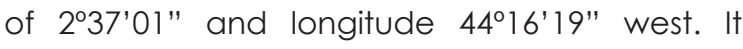
presents a hot and humid tropical climate, with rainy season from January to June and average precipitation of $1800 \mathrm{~mm}$ year- ${ }^{1}$.
The treatments consisted of combinations between the animal condition (castrated and non-castrated) and the use or not of supplementation with vitamin E (acetate alphatocopherol), comprising the following treatments: Uncastrated with vitamin E (UYE); Uncastrated without vitamin E (UNE); Castrated with vitamin E (CYE); Castrated without vitamin E (CNE). A 2 x 2 factorial design was used with two animal conditions, two conditions of supplementation with vitamin $\mathrm{E}$, and six replicates (animals). Goats with no defined racial pattern (SPRD) were used, with approximately 8 months of age and with an average initial live weight of $18 \mathrm{Kg}$.

The confinement was a masonry shed, leaked on its sides, with a roof fitted with a lantern and covered with fibre tile and concrete floor. The experimental animals were allocated to individual stalls, produced with metallic material, having an area of $1.50 \times 1.70 \mathrm{~m}$, totaling $2.55 \mathrm{~m}^{2}$. Each stall was equipped with a water dispenser, feeder and plastic salt shakers. The floor of the stalls was protected with a bed of sawdust shavings, with a slope of $5 \%$, for greater comfort of the animals.

The animals were fed roughage (Tifton-85 hay), concentrate, water supplied "ad libitum" and mineral mix. The diets were formulated to be isoproteic and isoenergetic (Table 1), calculated according to the requirements prescribed by the NRC (2007), for weight gain of $150 \mathrm{~g} /$ day, for animals weighing $20 \mathrm{Kg}$ of live weight.

Table 1. Percentage and chemical composition of the ingredients of the experimental ration of goats with no defined racial pattern (NDRP) castrated and uncastrated, supplemented with vitamin $\mathrm{E}$.

\begin{tabular}{|c|c|c|c|c|c|}
\hline \multirow{2}{*}{ Ingredient (\%) } & \multicolumn{2}{|c|}{ Condition } & \multirow{2}{*}{ Nutrient (\%) } & \multicolumn{2}{|c|}{ Condition } \\
\hline & Castrated & Uncastrated & & Castrated & Uncastrated \\
\hline Tifton-85 Hay & 38,28 & 42,58 & DM & 87,12 & 87,06 \\
\hline Corn & 36,70 & 36,99 & $\mathrm{CP}$ & 15,00 & 13,67 \\
\hline Soy & 14,73 & 11,36 & NDF & 38,26 & 38,01 \\
\hline Wheat & 9,13 & 8,01 & ADF & 20,14 & 20,01 \\
\hline \multirow[t]{3}{*}{ Limestone } & 1,13 & 1,03 & $\mathrm{EE}$ & 3,46 & 3,54 \\
\hline & & & TDN & 66,67 & 67,09 \\
\hline & & & $P$ & 0,72 & 0,33 \\
\hline
\end{tabular}

Supplementation was initiated in the period of adaptation of the animals until the last week of data collection, always occurring once a week. A dose of $3 \mathrm{ml}$ of vitamin $\mathrm{E}$ was administered subcutaneously, equivalent to $300 \mathrm{mg}$. The animals in the groups without supplementation received a placebo (saline solution) to undergo the same stress as the supplemented animals.

The confinement comprised a period of 14 first days intended for the animals to adapt to 
the experimental stalls and diets and 63 days of the experimental period for data collection.

For the analysis of environmental conditions, the values of temperature and humidity limits mentioned by Leite et al. (2012) were used, following their proposal to classify the situation of the animals: comfort, alertness, critical or lethal.

Table 2. Reference values for the comfort enthalpy index (CEI).

\begin{tabular}{ccc}
\hline \multirow{2}{*}{ Situation } & \multicolumn{2}{c}{ Limitations } \\
\cline { 2 - 3 } & Minimum & Maximum \\
\hline Comfort & 42,00 & 70,10 \\
Alert & 70,20 & 97,20 \\
Critical & 97,30 & 127,70 \\
Lethal & 127,80 & 166,80 \\
\hline
\end{tabular}

Enthalpy expresses the amount of thermal energy in KJ, contained in $1.0 \mathrm{Kg}$ of dry air. The equation proposed by Rodrigues et al. (2010) was used, considering the temperature, the relative humidity of the air and the local atmospheric pressure (Equation 1).

Equation 1.

$h=1,006 t+R H / P B * 10^{(7,5 t / 237,3+t) *}(71,28+0,052 t)$

Where, $h=$ enthalpy (kJ.kg dry air $\left.^{-1}\right) ; t=$ temperature $\left({ }^{\circ} \mathrm{C}\right) ; \mathrm{RH}=$ relative humidity of air $(\%)$;

Table 3. Climatic conditions data.
$P B=$ local barometric pressure $(\mathrm{mmHg})$.

The hair coat temperature and rectal temperature data were collected prior to weighing, within their own stalls, to interfere as little as possible in the daily habit of animals.

Infrared thermometers were used to measure the surface temperature of the animal's fur, at a distance of $5 \mathrm{~cm}$ from the cervical, thoracic and gluteal regions. Data were collected three times a week, at $9 \mathrm{~h}, 12 \mathrm{~h}$ and 15 h. Data on the climatic condition of the day are presented in Table 3.

\begin{tabular}{|c|c|c|c|c|c|c|c|c|c|}
\hline \multirow{2}{*}{ Time } & \multicolumn{2}{|c|}{ Temperature $\left({ }^{\circ} \mathrm{C}\right)$} & \multicolumn{2}{|c|}{ Humidity (\%) } & \multicolumn{2}{|c|}{ Dew point $\left({ }^{\circ} \mathrm{C}\right)$} & \multirow{2}{*}{$\begin{array}{l}\text { Wind } \\
(\mathrm{m} / \mathrm{s})\end{array}$} & \multirow{2}{*}{$\begin{array}{l}\text { Radiation } \\
\qquad\left(\mathrm{kJ} / \mathrm{m}^{2}\right)\end{array}$} & \multirow{2}{*}{$\begin{array}{l}\text { Rain } \\
\text { (mm) }\end{array}$} \\
\hline & Max. & Min. & Max. & Min. & Max. & Min. & & & \\
\hline 07 to $11 \mathrm{~h}$ & 28,20 & 26,45 & 79,25 & 71,25 & 22,88 & 21,75 & 2,50 & 1016,50 & 0,00 \\
\hline 11 to $15 \mathrm{~h}$ & 31,25 & 29,33 & 64,50 & 55,50 & 22,58 & 20,68 & 3,98 & 1815,50 & 0,00 \\
\hline 15 to $19 \mathrm{~h}$ & 30,28 & 29,03 & 64,50 & 57,50 & 21,78 & 20,53 & 3,53 & 1276,33 & 0,00 \\
\hline 19 to $23 \mathrm{~h}$ & 27,00 & 26,65 & 77,25 & 75,25 & 22,38 & 22,13 & 2,28 & $-0,12$ & 0,00 \\
\hline 23 to $03 \mathrm{~h}$ & 26,48 & 26,30 & 78,50 & 77,25 & 22,30 & 22,10 & 2,15 & $-3,52$ & 0,00 \\
\hline 03 to $07 \mathrm{~h}$ & 26,25 & 26,03 & 79,75 & 78,00 & 22,33 & 21,98 & 2,23 & $-3,53$ & 0,00 \\
\hline
\end{tabular}

The behavioral test was performed at 60 days of confinement, lasting 24 hours. Two observers were assigned to each treatment, taking turns between each other in shifts of 4 hours (six turns). During a few hours of the night preceding the day of the evaluation, the observers remained close to the stalls, in the same place they stayed during the evaluation, to accustom the animals to their presence. The assessments consisted of three types of measurements: Two instantaneous mode outlets at 10 min intervals (time consuming ration, ruminating time, time in other activities or idle time). The other type of measurement, called a set of specific activities (Frequency of salt intake, Frequency of urination, Frequency of defecation, Frequency of water intake) were also performed.

For data tabulation, we chose to divide the day into four-hour intervals, starting at 7:00 am. Thus, six evaluation periods were obtained (07 to $11 \mathrm{~h} ; 11$ to 15h; 15 to 19h; 19 to 23h, 23 to 03h and 03 to $07 \mathrm{~h}$ ), thus allowing separation of the interval considered more critical to the behavior of the animal, that is, the interval of $11 \mathrm{~h}$ to $15 \mathrm{~h}$, in which the solar radiation is more intense and the air temperature higher.

Data relating to time spent consuming ration, time ruminating, time in other activities or time spent idle were tabulated as sum of total time (within each interval of 4 hours) assigned for each activity. The aforementioned activities were tabulated in the form of frequency (number 
of times each animal, on the average of six, performed a given activity during the day, or during the interval of 4 hours).

The mean number of ruminating chews per ruminal bolus and the mean time spent chewing per ruminal bolus were obtained in three two-hour periods, registering three values distributed in the hours of 10 to $12 \mathrm{~h}, 14$ to $16 \mathrm{~h}$ and 18 to $20 \mathrm{~h}$, using a digital stopwatch. In the nocturnal observation of the animals, the environment was maintained with artificial illumination.

Results regarding the factors of ingestive behavior were obtained by the relationships:

Feeding efficiency $(\mathrm{FE})=$ Consumption of Dry Matter (CDM) / Feeding Time (FT);

Rumination Efficiency (RE) = Dry Matter Consumption (CMS) / Rumination Time (RT);

Rumination Efficiency of NDF (RENDF) = NDF Consumption (CNDF)/Rumination Time (RT);

Total Chewing Time $(\mathrm{TCT})=$ Feeding Time

(FT) + Rumination Time (RT);

Number of bolus $(\mathrm{BOL})=$ Rumination Time

(RT) / Chewing Time per Bolus (CTB);

Total Ruminating Chews (TRC) $=$ Number of bolus $(\mathrm{BOL}) *$ Number of Ruminating Chews per Bolus (NRCB).

Where, FE is feed efficiency (grams of $D M /$ hour); CDM is the consumption of DM (grams of DM/day); FT corresponds to the feeding time (hours/day); RE is the rumination efficiency (grams of DM/hour and grams of NDF/hour); RT is rumination time (hours/day and seconds/day): TCT is the total mastication time (hours/day); BOL, the number of bolus (no./day); CTB is the time of ruminating chewing per bolus (seconds/bolus); TRC, the number of ruminating chews (no./day); and $\mathrm{NRCB}$, the number of ruminating chews per bolus (no./bolus). The bolus was considered to be the portion of food that returns to the mouth to undergo the rumination process.

The data were submitted to analysis of variance and comparison of means using means of the Tukey test, at the $5 \%$ probability level, with the aid of the statistical program Infostat (Di Rienzo et al., 2018).

\section{Results and Discussion}

The time spent on rumination, other activities, the frequency of defecation and water consumption, were not influenced by animal (castrated or uncastrated) nor by supplementation with vitamin $\mathrm{E}$.

It was observed that UYE treatment animals presented a higher percentage of time spent feeding $(18.98 \% /$ day $)(P<0.05)$, equivalent to (273 minutes or 4:33 hours), a result different to that of the animals in UNE (13.42\%/day), which corresponded to 3:13 hours or 193 minutes of the day.

Some consumption response associated with vitamin Emay be related to the concentration of the supplement, which in the case of this experiment, the animals received a dosage of 3 $\mathrm{ml}$ or $300 \mathrm{IU}$. In a study conducted by Wang et al. (2016), the dosage used for goats was 100 IU (1 $\mathrm{ml}$ ), and yet the animals showed an adequate nutritional status. For this reason, uncastrated animals without vitamin E have spent more time eating food, probably to supply their nutritional needs.

It was possible to observe that the animals CNE remained longer in idle time $(P<0.05)$, representing a percentage of $53.93 \% /$ day, i.e. 12:53 hours, while the CYE animals remained idle 42.53\%/day, which corresponded to 10:12 hours.

As for the time spent on rumination, it can be said that the non-differentiation of the results has an explanation in the percentage of NDF diets, as their participation increases there is a longer retention time of the digestate in the rumen (Barreto et al., 2011).

There was an effect of the condition of the animal $(P<0.05)$ on salt consumption, where UNE animals presented a higher consumption frequency (2.03 no./day) than CNE (0.83 no./ day). Such consumption is also related to the accelerated growth of uncastrated animals. The consumption of salt was distributed during the day and with little intensity, is used to meet the minerals requirements of the animals (Pompeu et al., 2009).

Castration influenced the frequency of urination $(P<0.05)$ and although there was no significant difference in water consumption between the two physiological conditions, the 
CYE animals urinated more frequently (1.69 no./ day) than the UYE animals ( 1.44 no./day).

The dry matter contents of the diets of castrated and uncastrated goats were 87.12 and $87.06 \%$, respectively. In other words, the low moisture content of the rations caused the animals to obtain water from the drinkers, which maintained the consumption equality of this element.

In the case of castrated animals, the lowest frequency of urination may be associated with lower urethra development due to its early castration, and also as a function of diets with high proportions of concentrate (61.72\%) and the presence of phosphorus $(0.7 \%)$, because there is a decrease in saliva production, resulting in an increase in mineral excretion of the kidneys and subsequent elimination in the urine, which can cause a decrease in urinary flow (Cardoso Junior et al., 2017).

Table 4. Percentage of measurement of instantaneous activities and frequency of physiological activities.

\begin{tabular}{|c|c|c|c|c|c|}
\hline \multirow{2}{*}{ Variables } & \multirow{2}{*}{ Condition } & \multicolumn{2}{|c|}{ Vitamin E } & \multirow{2}{*}{ Mean } & \multirow{2}{*}{ CV (\%) } \\
\hline & & Yes & Not & & \\
\hline \multirow{3}{*}{ Feed ingestion (\%/dia) } & Uncastrated & $13,42 b$ & $18,98 \mathrm{a}$ & 16,20 & \\
\hline & Castrated & 16,78 & 15,39 & 16,08 & 57,20 \\
\hline & Mean & 15,10 & 17,19 & & \\
\hline \multirow{3}{*}{ Rumination (\%/day) } & Uncastrated & 15,74 & 17,93 & 16,84 & \\
\hline & Castrated & 19,79 & 15,16 & 17,47 & 65,12 \\
\hline & Mean & 17,77 & 16,55 & & \\
\hline \multirow{3}{*}{ Other activities (\%/day) } & Uncastrated & 19,21 & 15,39 & 17,03 & \\
\hline & Castrated & 15,40 & 15,50 & 15,45 & 68,51 \\
\hline & Mean & 17,30 & 15,45 & & \\
\hline \multirow{3}{*}{ Leisure (\%/day) } & Uncastrated & 51,62 & 47,68 & 49,65 & \\
\hline & Castrated & $42,53 b$ & $53,93 a$ & 48,23 & 32,62 \\
\hline & Mean & 47,08 & 50,81 & & \\
\hline \multirow{3}{*}{ Salt consumption (no./day) } & Uncastrated & 1,38 & $2,03 \mathrm{~A}$ & $1,71 \mathrm{~A}$ & \\
\hline & Castrated & 1,11 & 0,83 B & $0,97 \mathrm{~B}$ & 27,57 \\
\hline & Mean & 1,25 & 1,43 & & \\
\hline \multirow{3}{*}{ Urination (no./day) } & Uncastrated & 1,69 & 1,86 & $1,77 \mathrm{~A}$ & \\
\hline & Castrated & 1,44 & 1,16 & $1,30 \mathrm{~B}$ & 42,42 \\
\hline & Mean & 1,57 & 1,51 & & \\
\hline \multirow{3}{*}{ Defecation (no./day) } & Uncastrated & 0,72 & 1,25 & 0,98 & \\
\hline & Castrated & 0,97 & 0,72 & 0,85 & 56,12 \\
\hline & Mean & 0,84 & 0,99 & & \\
\hline \multirow{3}{*}{ Drinking water (no./day) } & Uncastrated & 0,55 & 1,30 & 0,93 & \\
\hline & Castrated & 1,02 & 0,86 & 0,94 & 48,15 \\
\hline & Mean & 0,79 & 1,08 & & \\
\hline
\end{tabular}

From dividing the intervals, it was possible to observe with more clarity the amount of time that the animals used for each activity.

For feed intake, it was observed that the animals spent more time consuming ration in the intervals between 07 to $11 \mathrm{~h}$ and 15 to $19 \mathrm{~h}$. This behavior can be attributed to the time of supply of diets in the trough, which in this study were divided into two stages, at 8 and $17 \mathrm{~h}$.

It was also noted that in these two intervals, animals of the UNE treatment presented different behaviors, where, in the interval from 07 to $11 \mathrm{~h}$ their percentage of time spent with feed intake was the lowest among all treatments (33.13\% or 79 minutes), whereas the period from
15 to $19 \mathrm{~h}$, presented the highest percentage of feeding time $(40.97 \%$ or 98 minutes).

There was also a decrease in feed intake between 11 and $15 \mathrm{~h}$, a period that did not present the highest environmental temperature averages, with averages above $33^{\circ} \mathrm{C}$, that is, outside the thermal comfort zone for adult goats $\left(20-30^{\circ} \mathrm{C}\right)$.

These results have a direct relation with the natural behavior of goats, where the animals use more time if fed during the day, quickly ingesting the maximum amount of food (Paulo \& Lopes, 2014)(Figure 1).

Regarding the time spent in rumination, the intervals between 11 and $15 \mathrm{~h}$ were the first 
used for rumination, and the intervals between $19 \mathrm{~h}$ and $07 \mathrm{~h}$ in the morning were those with the highest time spent for the same activity. In the interval from 03 to $07 \mathrm{~h}$, the goats of the UYE treatment remained less ruminating (34.73\%), corresponding to 83 minutes.

It was possible to observe that in all treatments the rumination process started one to two hours after feed intake. According to Vieira et al. (2011) the rumination peaks between $01 \mathrm{~h}$ and $07 \mathrm{~h}$ are due to the rest of the animals, where the activities alternate between the processing of the ingested food and idleness (Figure 2).

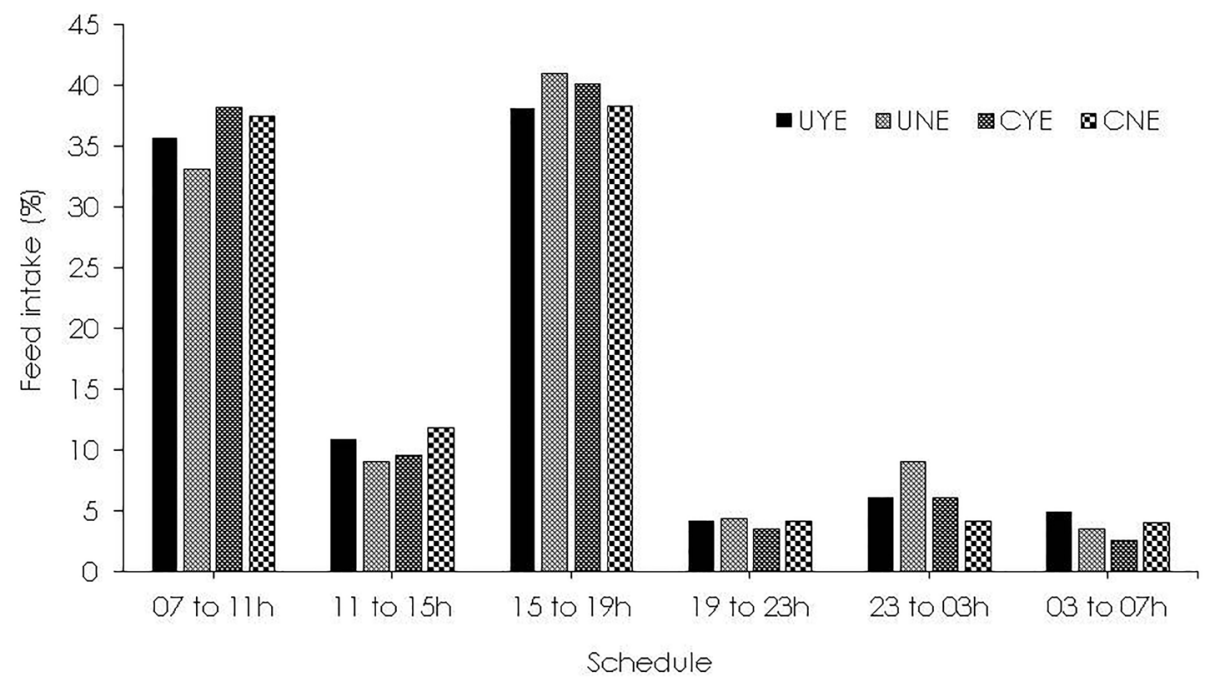

Figure 1. Percentage graph of feed intake activity in the 24 hour period.

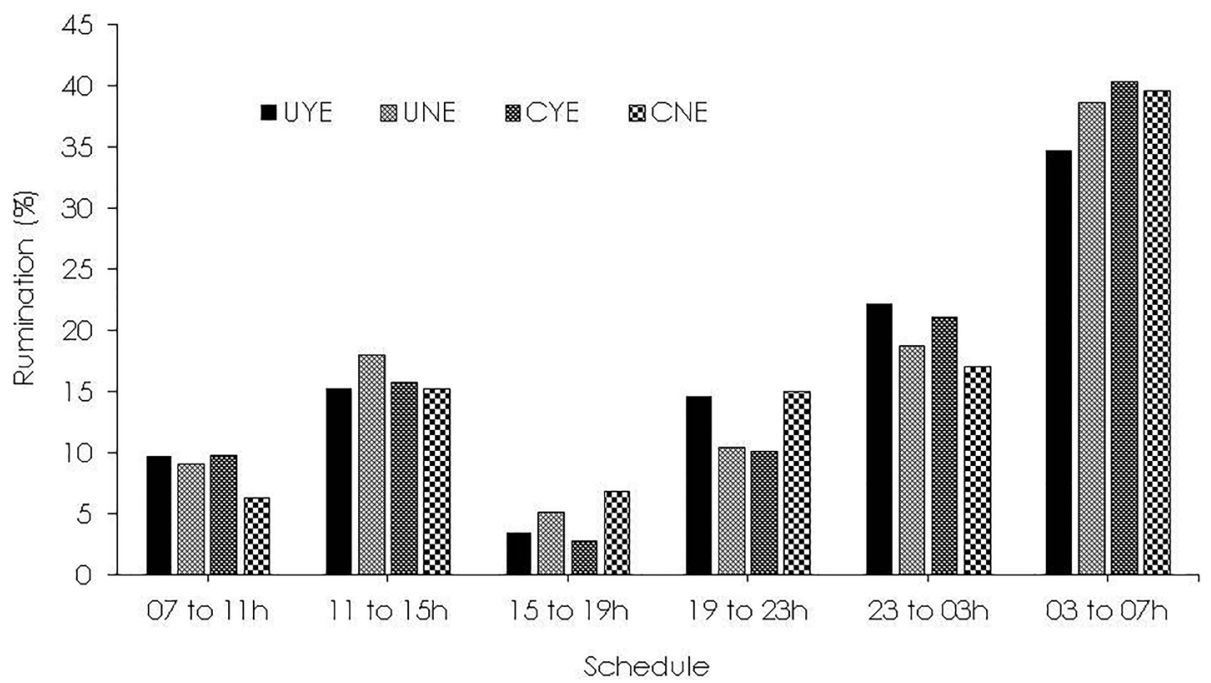

Figure 2. Percentage of rumination activity in the period of 24 hours.

The permanence of the animals at leisure/idleness was more prominent in the intervals between 19 and $23 \mathrm{~h}$, however, this behavior remained constant and showed lower peaks in the other periods of observation (Figure 3).

The duration of idleness has an inverse relationship with rumination, because the longer the animals spend ruminating, the lower their time of permanence. The same behavior was observed in this study, through a decrease of permance in idleness, by animals of all treatments, in the period from 23 to $07 \mathrm{~h}$ as the rumination activity increased.

It is important to highlight the longer period of idleness in CNE treatment animals in most of the evaluation periods, especially from 19 to $23 \mathrm{~h}$ and from 23 to $03 \mathrm{~h}(\mathrm{P}<0.05)$, with activity percentages at 77.08 (3:05 hours) and $72.22 \%$ (2:53 hours), respectively. One of the explanations can be through the satiety promoted by diets with equal balance between roughages and 
concentrates, because the greater proportion of hay promotes the faster filling of the rumen, leading the animals to idle state (Cândido et al., $2011)$. This behavior may also be related to the docility acquired after the castration process, since the animals of this treatment spent more time lying idle without performing any rumination movement.

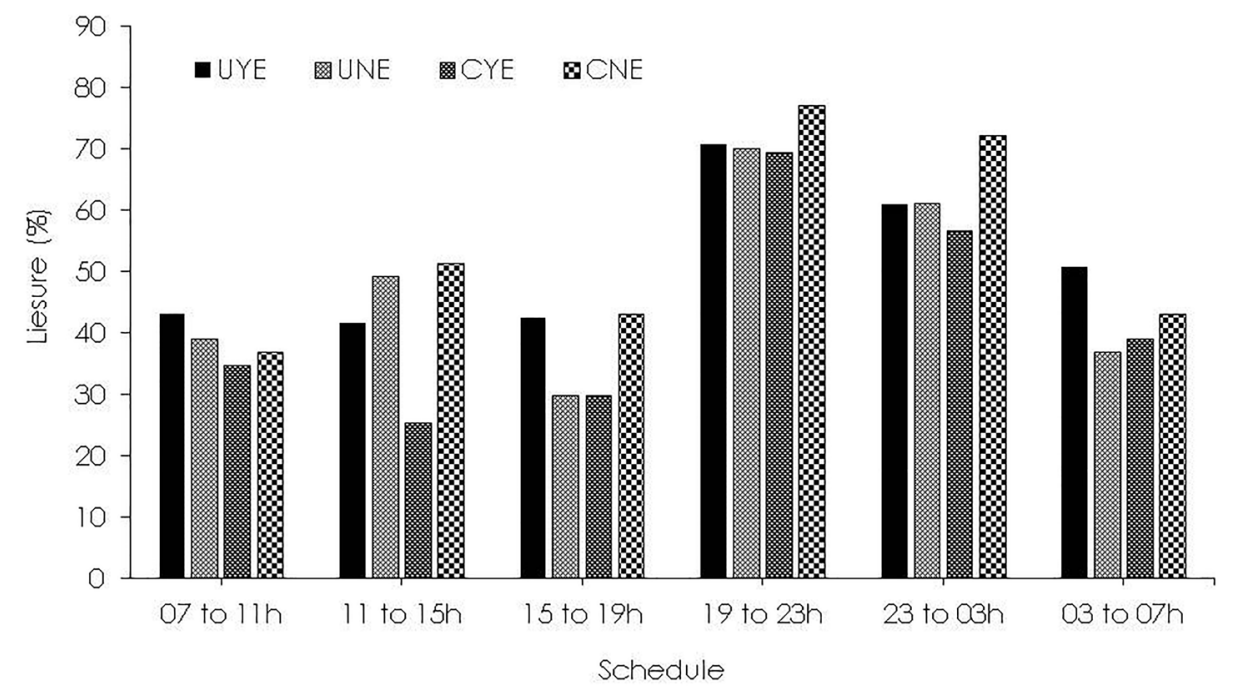

Figure 3. Percentage of leisure activity in the 24-hour period.

The other activities carried out were characterized by the behavior of the animals when they used their teeth, their horns, their legs, their own stall or their equipment (drinker, feeder and salt) to scratch, when they were standing or walking, when they interacted with animals from the neighboring stalls (Figure 4).

It was observed that in the period from 7 to $11 \mathrm{~h}$ and from 11 to $15 \mathrm{~h}$, animals of the UYE treatment stayed longer performing other activities. In the range of 15 to $19 \mathrm{~h}$, the CYE goats devoted a higher percentage (27.08\%) to these activities of interaction with the environment, the equivalent of 1:05 hours.

These responses may have negative correlation with leisure periods $(P<0.05 ; r=-0.4959)$ where animals in the same range, interacted less with the environment due to leisure activity and rumination, which is intrinsic to the behavior of goats (Araújo et al., 2012).

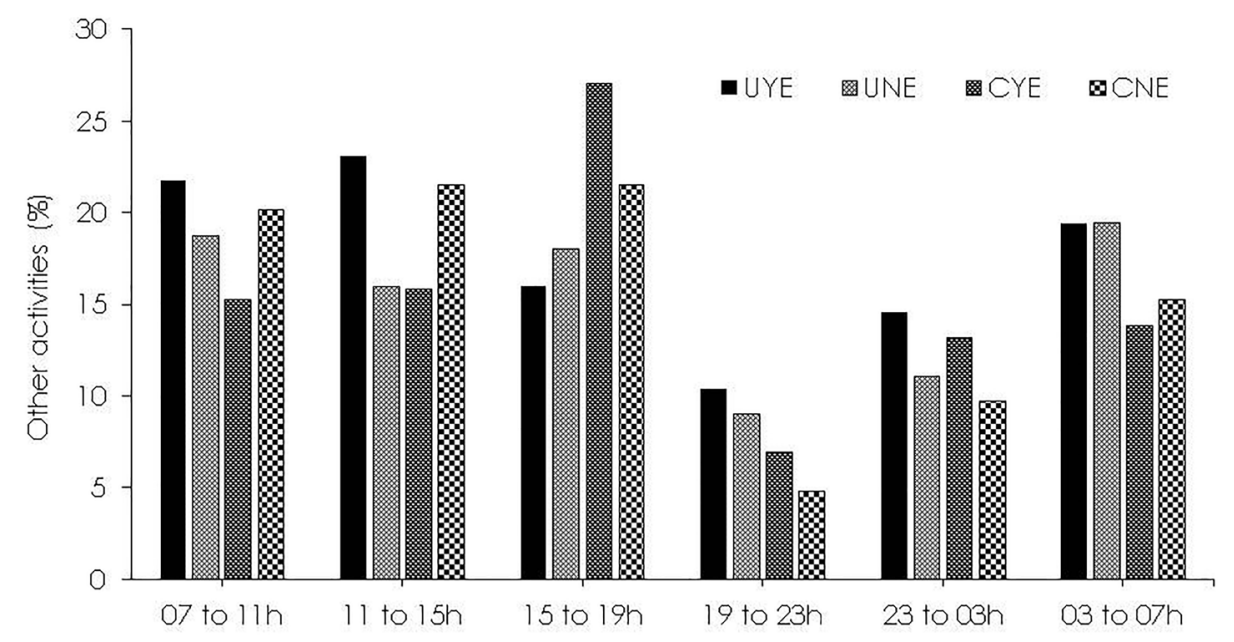

Figure 4. Percentage of other activities in the 24-hour Period.

It was observed that in the periods from 19 to $23 \mathrm{~h}, 23$ to $03 \mathrm{~h}$ and 03 to $07 \mathrm{~h}, \mathrm{RH}$ remained outside the ideal values for domestic animals (between $50-70 \%$ ), the $\mathrm{RH}$ values found were
$71.05,70.26$ and $70.22 \%$, respectively. These data also explain the Comfort Enthalpy Index (CEI), classified in the alert situation, as well as in the intervals of 07 to $11 \mathrm{~h}$ and 11 to $15 \mathrm{~h}$ (Table 5). 
Table 5. Mean values for temperature, relative air humidity (RH) and comfort enthalpy index (CEI) according to the intervals of the observations.

\begin{tabular}{cccc}
\hline Hour & Temperature $\left({ }^{\circ} \mathrm{C}\right)$ & $\mathrm{RH}(\%)$ & $\mathrm{CEI}$ \\
\hline 07 tol $\mathrm{h}$ & 29,95 & 64,38 & 72,64 \\
11 to $5 \mathrm{~h}$ & 31,62 & 55,48 & 72,28 \\
15 to $19 \mathrm{~h}$ & 30,07 & 59,63 & 69,93 \\
19 to $23 \mathrm{~h}$ & 27,27 & 76,90 & 71,05 \\
23 to $03 \mathrm{~h}$ & 26,74 & 78,90 & 70,26 \\
03 to 07 $\mathrm{h}$ & 26,66 & 79,36 & 70,22 \\
\hline
\end{tabular}

Leite et al. (2012), in work with the influence of bioclimatic factors on the productive and physiological indexes of confined goats, observed in the hours of $3 \mathrm{~h}$ and $6 \mathrm{~h}$, values of RH above the thermal comfort zone with values of 88.1 and $71.1 \%$, respectively.

When this zone is exceeded, the animals may present caloric stress, and trigger their thermoregulatory mechanisms, leaving background activities such as dry matter intake and rumination, with the loss of their productive performance (Souza et al., 2010).

However, in the period from 15 to $19 \mathrm{~h}$, the average temperature was observed above the thermal comfort zone $\left(30.07^{\circ} \mathrm{C}\right)$, which did not affect the CEl (69.93) classified in the comfort situation, allowing the highest consumption of feed for all treatments. In addition, the use of vitamin E may favor the stabilization of some physiological parameters related to thermal stress (rectal temperature and respiratory rate) at a time closer to the neutral zone (Wang et al., 2016). The adaptive issues of the animals were also added to the more severe temperature conditions, so that their productive performance is unaffected.

The feed efficiency and rumination efficiency of NDF presented a difference ( $P>0.05)$ in none of the treatments. However, there was an influence of the animal condition $(P<0.05)$ on dry matter rumination efficiency, in which uncastrated animals were more efficient than castrated animals, i.e they consumed a greater amount of dry matter per unit of time.

It is important to emphasize that the diets supplied, were formulated according to the nutritional requirement of each category, observing the ratio of roughage : concentrate (uncastrated 43:57) (castrated 38:62). Although the percentage of time spent on feed intake was on average 16,09\%/day (3:52 hours) and with the roughage participation of around $42 \%$ in diets of uncastrated animals, this category showed greater versatility in harnessing food, which influenced the shorter rumination time, possibly increasing its efficiency in dry matter rumination (Table 6).

These results may also be related to the caloric increment promoted by the diets, which according to Sousa et al. (2011), causes changes in animal behavior, such as reduction in forage intake in relation to concentrate, which promotes heat dissipation and consequent reduction in production.

The chewing time, number of bolus, number of chews, number of chews per bolus and chewing time were not influenced $(P>0.05)$ by vitamin $\mathrm{E}$ or not supplementation, nor of animal condition (uncastred and castrated). These results were presented as expected, since the number of ruminating chews per day is directly proportional to the number of ruminal bolus, that is, the higher the number of ruminal bolus per day, the greater the number of daily chewing (Barreto et al., 2011).

Such behavior can also be explained by the proportions of NDF, since these present similar values in both diets. In addition, positive correlations between total chewing time and number of bolus ( $P<0.05 ; r=0.9505)$ justified these results.

Therefore, the longer time spent on chewing reveals the ability of the caprine species to harness food of inferior quality, compensating this deficit through the stimulation of saliva production, rich in buffering compounds, which neutralize the acids originated from the fermentation of the organic matter, providing a better ruminal environment (Souza et al., 2010). 
Table 6. Mean values for the parameters of ingestive behavior.

\begin{tabular}{|c|c|c|c|c|c|}
\hline \multirow{2}{*}{ Variables } & \multirow{2}{*}{ Condition } & \multicolumn{2}{|c|}{ Vitamin E } & \multirow{2}{*}{ Mean } & \multirow{2}{*}{ CV $1 \%$} \\
\hline & & Yes & Not & & \\
\hline \multirow{3}{*}{$\begin{array}{l}\text { Feed efficiency } \\
\text { (Kg DM/hour) }\end{array}$} & Uncastrated & 0,15 & 0,14 & 0,14 & \\
\hline & Castrated & 0,09 & 0,13 & 0,11 & 41,32 \\
\hline & Mean & 0,12 & 0,13 & & \\
\hline \multirow{3}{*}{$\begin{array}{l}\text { Efficiency of rumination of MS } \\
\qquad \text { (Kg DM/hour) }\end{array}$} & Uncastrated & 0,13 & 0,15 & $0,14 \mathrm{~A}$ & \\
\hline & Castrated & 0,08 & 0,09 & $0,08 \mathrm{~B}$ & 43,72 \\
\hline & Mean & 0,10 & 0,12 & & \\
\hline \multirow{3}{*}{$\begin{array}{l}\text { Efficiency of rumination of NDF (Kg } \\
\qquad \mathrm{DM} / \text { hour) }\end{array}$} & Uncastrated & 0,04 & 0,05 & 0,05 & \\
\hline & Castrated & 0,04 & 0,03 & 0,03 & 44,22 \\
\hline & Mean & 0,04 & 0,04 & & \\
\hline \multirow{3}{*}{$\begin{array}{l}\text { Total chewing time } \\
\text { (hours/day) }\end{array}$} & Uncastrated & 7,00 & 8,86 & 7,93 & \\
\hline & Castrated & 9,47 & 8,63 & 9,05 & 21,68 \\
\hline & Mean & 8,23 & 8,75 & & \\
\hline \multirow{3}{*}{$\begin{array}{l}\text { Number of bolus } \\
\text { (no./day) }\end{array}$} & Uncastrated & 5,67 & 6,38 & 6,02 & \\
\hline & Castrated & 7,05 & 6,44 & 6,74 & 30,90 \\
\hline & Mean & 6,36 & 6,41 & & \\
\hline \multirow{3}{*}{$\begin{array}{l}\text { Number of chews } \\
\text { (no./day) }\end{array}$} & Uncastrated & 270,19 & 305,98 & 288,08 & \\
\hline & Castrated & 352,73 & 324,01 & 338,37 & 35,06 \\
\hline & Mean & 311,46 & 315,00 & & \\
\hline \multirow{3}{*}{$\begin{array}{l}\text { Number of chews per bolus } \\
\text { (no./bolus) }\end{array}$} & Uncastrated & 46,99 & 47,77 & 47,38 & \\
\hline & Castrated & 49,97 & 50,06 & 50,01 & 18,86 \\
\hline & Mean & 48,48 & 48,92 & & \\
\hline \multirow{3}{*}{$\begin{array}{l}\text { Chewing Time } \\
\text { (seconds/bolus) }\end{array}$} & Uncastrated & 39,5 & 40,12 & 39,81 & \\
\hline & Castrated & 44,18 & 45,92 & 45,05 & 16,27 \\
\hline & Mean & 41,84 & 43,02 & & \\
\hline
\end{tabular}

\section{Conclusions}

Vitamin E had little influence on the ethological behavior of goats, however, the percentage of time spent with feed intake decreased for animals that received supplementation.

Castration is directly related to the behavioral parameters of goats, such as leisure time, time spent on other activities and frequency of urination.

In addition, climatic variables should be considered as strong influencers of the ethological, ingestive and productive responses of these animals, even if their rusticity guarantees them greater resistance to more severe environmental conditions.

\section{Acknowledgement}

To IFMA - Campus São Luis - Maracanã and FAPEMA, for the support to carry out this research.

\section{References}

Araújo, K.T.A.,Furtado, F.L.,Nascimento, A.L.A.,Furtado, D.A., Nascimento, J.W. B. 2012. Comportamento de caprinos nativos mantidos sobdiferentes temperaturas em ambiente climatizado. Revista Educação Agrícola Superior. 27: 59-64.

Barreto, L.M.G.,Medeiros, A.N.,Batista, A.M.V.,Furtado, D.A., Araújo, G.G.L., Lisboa, A.C.C., Paulo, J.L.A., Souza, C.M.S. 2011. Comportamento ingestivo de caprinos das raças Moxotó e Canindé em confinamento recebendo dois níveis de energia na dieta. Revista Brasileira de Zootecnia. 40: 834-842.

Cândido, E.P., Pereira, G.F., Barros, N.A.M.T., Guilhermino, M.M., Cavalcanti, F.A.L., Fernandes Júnior, F.C. 2011. Comportamento ingestivo de cabras de aptidão leiteira alimentadas com feno de flor de seda. Agropecuária Técnica. 32: 145-151.

Cardoso Júnior, F.C, Silva, N.C.B., Silva, Y.A., Pereira, A.M., Mendonça, W.S., Feitosa Junior, F.S., Tenório, T.G.S. 2017. Urolitíase obstrutiva em ovinos: Revisão. Pubvet. 11: 1028-1035.

Di Rienzo J.A., Casanoves F., Balzarini M.G., Gonzalez L., Tablada M., Robledo C.W. 2018. InfoStat versión 2018. Centro de Transferencia InfoStat, FCA, Universidad Nacional de Córdoba, Argentina.

Kasapidou, E.,Wood, J.D.,Richardson,R.I. 2012. Effect of Vitamin E supplementation and diet on fatty acid composition and on meat colour and 
lipid oxidation of lamb leg steaks displayed in modified atmosphere packs. Meat Science. 90: 908-916.

Leite, J.R.S., Furtado, D.A., Leal, A.F., Souza, B.B., Silva, A.S. 2012. Influência de fatores bioclimáticos nos índices produtivos e fisiológicos de caprinos nativos confinados. Revista Brasileira de Engenharia Agrícola e Ambiental. 16: 443-448.

NRC - National Research Council. 2007.Nutrient requirements of small ruminants: sheep, goats, cervids, and New World camelids. National Academic Press, Washington, USA. 292p.

Paulo, J.L.A, Lopes, F.A. 2014. Daily activity patterns of Saanen goats in the semi-arid northeast of Brazil. Revista Brasileira de Zootecnia. 43: 464-470.

Pompeu, R.C.F.F., Rogério, M.C.P., Cândido, M.J.D., Neiva, J.N.M., Guerra, J.L.L., Gonçalves, J.S. 2009. Comportamento de ovinos em capimtanzânia sob lotação rotativa com quatro níveis de suplementação concentrada. Revista Brasileira de Zootecnia. 38: 374-383.

Rodrigues, V.C., Silva, I.J.O., Vieira, F.M.C., Nascimento, S.T. 2010. A correct enthalpy relationship as thermal comfort índex for livestock. International Journal Biometeorology. 55: 455459.

Sousa, B.B., Andrade, I.S., Pereira Filho, J.M., Silva, A.M.A. 2011. Efeito do ambiente e da suplementação no comportamento alimentar e no desempenho de cordeiros no semiárido. Revista Caatinga. 24: 123 - 129.

Souza, E.J.O., Guim, A., Batista, A.M.V., Albuquerque, D. B., Monteiro, C.C.F., Zumba, E.R.F., TORRES, T.R. 2010. Comportamento ingestivo e ingestão de água em caprinos e ovinos alimentados com feno e silagem de Maniçoba. Revista Brasileira de Saúde e Produção Animal. 11: 1056-1067.

Vieira, M.M.M.,Cândido, M.J.D., Bomfim, M.A.D., Severino, L.S.,Pereira, E.S.,Beserra, L.T.,Meneses, A.J.G., Fernandes, J.B.F. 2011 . Comportamento ingestivo de ovinos alimentados com rações contendo quatro níveis de inclusão do farelo de mamona. Revista Ceres. 58: 444-451.

Wang, L., Wang, Z., Zou, H., Peng, Q. 2016. Yeast Culture and Vitamin E Supplementation Alleviates Heat Stress in Dairy Goats. Asian-Australasian Jounal of Animal Science. 29: 814-822. 